\title{
Effect of Atrial Peptides on Aldosterone Production
}

Keiichiro Atarashi, Patrick J. Mulrow, and Roberto Franco-Saenz

Department of Medicine, Medical College of Ohio, Toledo, Ohio 43699

\section{Abstract}

This study examines the effects of the synthetic atrial peptides (atriopeptin I, II, and III) on aldosterone and corticosterone production by rat adrenal cell suspensions. Furthermore, we studied the effect of atriopeptin II infusion on the plasma aldosterone response to angiotensin $\mathrm{II}$ in the rat in vivo. Atriopeptin I, II, and III decreased aldosterone release from zona glomerulosa cells in a dose-dependent fashion. $10 \mathrm{pM}$ atriopeptin $\mathrm{II}$ inhibited basal aldosterone release significantly $(P<0.01)$, and $10 \mathrm{nM}$ atriopeptin II or III lowered it by $79 \%$. Atriopeptin II decreased the sensitivity of the glomerulosa cells to adrenocorticotropic hormone (ACTH) and angiotensin II. Atriopeptin II had no effect on basal or ACTH-stimulated corticosterone release by fasciculata-medullary cells.

In vivo infusions of angiotensin II with or without simultaneous infusions of atriopeptin II showed that atriopeptin II significantly inhibited the aldosterone response to angiotensin II. This inhibition by atriopeptin II was independent of any effect on plasma renin activity, serum potassium, or ACTH.

These data raise the possibility that the atrial natriuretic peptides may affect sodium excretion by the kidney, not only directly, but also indirectly through the inhibition of aldosterone production.

\section{Introduction}

Recently, a number of peptides with potent natriuretic, diuretic $(1-7)$, and vasorelaxant activities $(8-10)$ have been isolated from mammalian atria. Mammalian atrial cardiocytes contain specific granules which morphologically resemble those found in peptidesecreting cells (11). These granules are probably storage sites of the atrial natriuretic peptide $(12,13)$. Atrial natriuretic factor induces natriuresis and diuresis by a direct action on the kidney (4). Earlier studies of the regulation of aldosterone secretion suggested the presence of an inhibitor of aldosterone secretion. Anderson et al. (14) showed that stretching the right atrium of the dog decreased aldosterone secretion, and in 1964, Gann and Travis (15) presented evidence supporting the possibility of an inhibitor of aldosterone secretion.

In a recent report we showed that crude atrial extracts caused

This work was published, in part, in abstract form in 1984. Clin. Res. 32:785.

Address reprint requests to Dr. Franco-Saenz, Division of Endocrinology, Department of Medicine, Medical College of Ohio, C.S. 10008, Toledo, OH 43699.

Received for publication 4 January 1985.

J. Clin. Invest.

(c) The American Society for Clinical Investigation, Inc. $0021-9738 / 85 / 11 / 1807 / 05 \$ 1.00$

Volume 76, November 1985, 1807-1811 a significant dose-dependent inhibition of aldosterone production in a glomerulosa cell preparation from rat adrenals. Furthermore, we showed that a 1:500 dilution of the atrial extract decreased the sensitivity of the glomerulosa cells to adrenocorticotropic hormone (ACTH) ${ }^{1}$ and angiotensin II (AII). The aldosteroneinhibiting activity of the atrial extract was abolished by treatment with trypsin, suggesting that the active factor was a peptide (16). Currie et al. and Geller et al. (8-9) isolated and characterized atriopeptins I, II, and III (ApI, II, and III), three low molecularweight peptides, from rat atria. These peptides contain 21,23 , and 24 amino acid residues, respectively, and have potent natriuretic, diuretic, and smooth-muscle relaxant activities. A longer peptide, cardionatrin 1-28, was first isolated and sequenced by Flynn et al. (7). Similarly, Kangawa and Matsuo (17) reported on the complete amino acid sequence of a human atrial natriuretic peptide. The human peptide contains 28 amino acids and has been named alpha human atrial natriuretic polypeptide. The sequence analysis of the complementary DNA for the precursor for rat atrial natriuretic factor has been performed by several laboratories (18-22). The precursor peptide contains 152 amino acids, including a signal peptide of 25 amino acids. Atriopeptin I, II, and III correspond to the carboxy terminal portion of the molecule. The amino terminal end contains cardiodilatin, a 7,500-mol wt peptide that has vasodilatory, but not natriuretic or diuretic, properties (22). The natural processing products for the natriuretic factor are not known. More recently we reported that synthetic atriopeptin I is one of the aldosterone-inhibiting factors contained in atrial extract (23). Atriopeptin I inhibited basal aldosterone production and decreased the sensitivity of the glomerulosa cells to ACTH and angiotensin II (23). The effect of atriopeptin I was similar to that of the crude atrial extract (23).

In the present study we examined the effect of synthetic atriopeptin I, II, and III on aldosterone and corticosterone production by rat adrenal cell suspensions in vitro, and the effects of atriopeptin II on the aldosterone dose-response curve to ACTH and angiotensin II. Moreover, we investigated the effect of atriopeptin II infusion on the plasma aldosterone-elicited response to angiotensin II infusions in vivo.

\section{Methods}

Materials. Synthetic atriopeptin I, II, and III were purchased from Peninsula Laboratories (Belmont, CA). It is described as being $98 \%$ pure by thin-layer chromatography and high performance liquid chromatography and as having a marked natriuretic effect when $1 \mathrm{nM}$ is assayed in rats. Synthetic 1-24 ACTH, synthetic ( $\mathrm{Asp}^{1}$, $\mathrm{Ile}^{5}$ ) angiotensin II, and bovine serum albumin (BSA) were obtained from Sigma Chemical Company (St. Louis, MO), collagenase from Worthington Diagnostics Div., Millipore Corp. (Freehold, NJ), and Medium 199 from Gibco (Grand Island, NY).

1. Abbreviations used in this paper: $\mathrm{ACTH}$, adrenocorticotropic hormone; AII, angiotensin II; Ap I, II, and III, atriopeptins I, II, and III; PRA, plasma renin activity. 
In vitro experiments. Female Sprague-Dawley rats $(\sim 180-230 \mathrm{~g})$ maintained on a regular sodium diet (Wayne Lab-Blox; Allied Mills, Chicago, IL) were used in each experiment. The rats were killed by decapitation and the adrenal glands were removed and separated into capsular and decapsular portions as previously described (24). Each portion was incubated with $2 \mathrm{mg} / \mathrm{ml}$ collagenase in Medium 199 for $30 \mathrm{~min}$ at $37^{\circ} \mathrm{C}$ under $95 \% \mathrm{O}_{2}$ and $5 \% \mathrm{CO}_{2}$. Medium 199 containing $2 \mathrm{mg} / \mathrm{ml}$ BSA was added to the collagenase-treated tissues, and they were dispersed by repeated aspiration using a pipette. The cell suspensions were filtered through gauze into $50-\mathrm{ml}$ polyethylene centrifugation tubes and pelleted by centrifugation at $100 \mathrm{~g}$ for $15 \mathrm{~min}$ at $4^{\circ} \mathrm{C}$. The cell pellets were resuspended in fresh Medium 199 containing $2 \mathrm{mg} / \mathrm{ml} \mathrm{BSA}$. In this capsular cell suspension, contamination with zona fasciculata cells is $7.1 \pm 0.9 \%$ (mean \pm SE).

The collagenase-dispersed capsular (mainly zona glomerulosa) and decapsular cells (fasciculata-medullary) (average cell counts, 60,000/tube) were incubated in duplicate in $1 \mathrm{ml}$ of Medium 199 containing $2 \mathrm{mg} /$ $\mathrm{ml}$ BSA with various amounts of atriopeptin I, II, or III (1 pM to 10 $\mathrm{nM}$ ) for $2 \mathrm{~h}$ at $37^{\circ} \mathrm{C}$ under $95 \% \mathrm{O}_{2}$ and $5 \% \mathrm{CO}_{2}$. To examine the effects of atriopeptin II on the aldosterone dose-response curves to ACTH and angiotensin II, the glomerulosa cells were incubated with various amounts of ACTH and angiotensin II ( $10 \mathrm{pM}$ to $1 \mu \mathrm{M})$ in the presence and absence of $10 \mathrm{nM}$ atriopeptin II. To study the effect of atriopeptin II on corticosterone production, the fasciculata cells were incubated with different concentrations of ACTH $(10 \mathrm{pM}$ to $10 \mathrm{nM})$ in the presence and absence of atriopeptin II (10 nM).

In vivo experiments. Female Sprague-Dawley rats $(\sim 200 \mathrm{~g})$ maintained on a normal sodium diet were used. Polyethylene catheters (PE 50) were implanted into the right common carotid artery and the internal jugular vein under pentobarbital anesthesia $(35 \mathrm{mg} / \mathrm{kg}$ i.p.) $48 \mathrm{~h}$ before the experiment. All catheters were led subcutaneously to the back of the neck and exteriorized. The catheters were flushed with isotonic saline and filled with heparinized saline to keep their patency. $2 \mathrm{~h}$ before the experiment the rats were given dexamethasone phosphate $(1.0 \mathrm{mg} / \mathrm{kg}$ Decadron ${ }^{\oplus}$ ) intraperitoneally. $2 \mathrm{~h}$ after dexamethasone administration $0.6 \mathrm{ml}$ blood was taken from the carotid catheter, and blood loss was replaced with the same volume of isotonic saline. Subsequently, angiotensin II $(0.2 \mathrm{nM} / \mathrm{kg}$ per $\mathrm{min})$ was infused continuously through the jugular catheter with and without atriopeptin II $(10 \mathrm{nM} / \mathrm{kg}$ by bolus followed by either $1 \mathrm{nM} / \mathrm{kg}$ per min [four rats] or $2 \mathrm{nM} / \mathrm{kg}$ per min [four rats]) for $30 \mathrm{~min}$. These peptides were infused in a volume of $9.6 \mu \mathrm{l}$ isotonic saline/min using a compact infusion pump (model 975; Harvard Apparatus Co., Inc. S. Natick, MA). $3 \mathrm{ml}$ of blood was taken from the carotid artery after $30 \mathrm{~min}$ of infusion.

Plasma aldosterone was measured before and after infusion. Plasma renin activity (PRA), corticosterone, potassium, and hematocrit were determined after infusion.

Aldosterone and corticosterone in the incubation media were measured by highly specific radioimmunoassay as previously described (2526). PRA was measured by radioimmunoassay using a Becton-Dickinson kit (Becton, Dickinson and Co., Oxnard, CA). Plasma potassium was measured by flame-photometer. Significance was calculated by unpaired Student's $t$ test, one-way analysis of variance, and Scheffe's multiple range analysis. A $P$ value of $<0.05$ was considered significant.

\section{Results}

In vitro experiments. Fig. 1 shows the effect of the atriopeptins on aldosterone release from the capsular cells. Atriopeptins decreased aldosterone release from the capsular cells in a dosedependent fashion. Significant inhibition of basal aldosterone production was observed with $10 \mathrm{pM}$ or greater dose of atriopeptin II, while atriopeptin I only caused significant inhibition at concentrations of $1 \mathrm{nM}$ or higher. Atriopeptin II and III had similar inhibitory effects and seemed to be more potent than atriopeptin I. However, the maximal aldosterone inhibition by

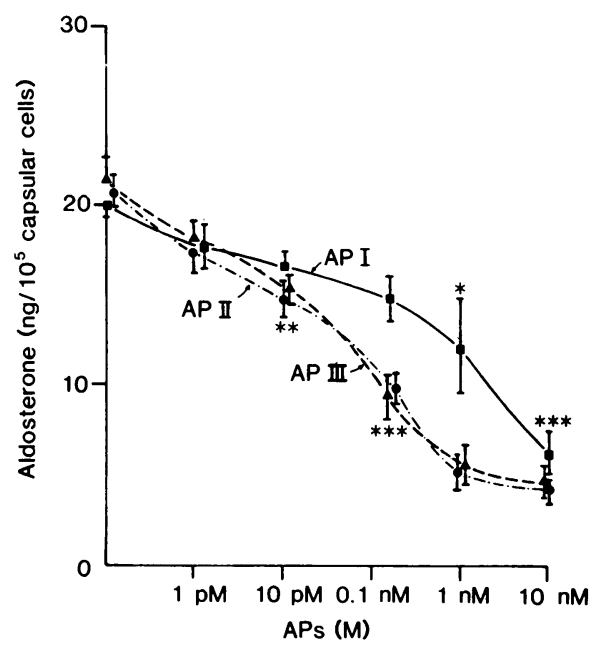

Figure 1. Inhibition of aldosterone secretion in unstimulated capsular cells by atriopeptin I, II, and III. Each point represents the mean \pm SE of four to six experiments done in duplicate. Ap I, $n=4$; Ap II, $n=6$; Ap III, $n=4$. Atriopeptin concentrations are expressed as moles per liter of incubation medium. Asterisks indicate values significantly different from the control value: ${ }^{*}(P<0.05),{ }^{* *}(P<0.01),{ }^{* * *}(P$ $<0.001)$. Significance calculated by one-way analysis of variance and Scheffe's multiple range analysis.

atriopeptin I was nearly the same as those of atriopeptin II and III. $10 \mathrm{nM}$ atriopeptin I lowered basal aldosterone release by $69 \%$, while $10 \mathrm{nM}$ atriopeptin II and III decreased it by $\sim 80 \%$.

Fig. 2 shows the effects of atriopeptin II on the aldosterone dose-response curve to ACTH. $10 \mathrm{nM}$ atriopeptin II reduced the sensitivity of the glomerulosa cells to ACTH and shifted the dose-response curve to the right $\left(\mathrm{ED}_{50}\right.$ with atriopeptin II was $\sim 1 \mathrm{nM} \mathrm{ACTH}$, and without atriopeptin II was $0.1 \mathrm{nM} \mathrm{ACTH).}$ However, at higher concentrations, the inhibitory effect of atriopeptin II is reduced and the maximal aldosterone response to a $0.1-\mu \mathrm{M}$ dose of $\mathrm{ACTH}$ was the same with or without atriopeptin II (response to $0.1 \mu \mathrm{M}$ ACTH $=81.3 \pm 3.7$ vs. $0.1 \mu \mathrm{M}$ ACTH + Ap II $=82.7 \pm 4.1=0 \%$ inhibition).

As shown in Fig. 3, the inhibition of the action of angiotensin II was even more striking. The $\mathrm{ED}_{50}$ for angiotensin II with atriopeptin II was $0.5 \mathrm{nM}$, and without atriopeptin II was $0.1 \mathrm{nM}$. In contrast to the ability of high doses of ACTH to overcome the inhibition of atriopeptin II, high doses of angiotensin II did not overcome the inhibition. The maximal aldosterone response was to a dose of $1 \mathrm{nM}$ angiotensin II and was significantly in-

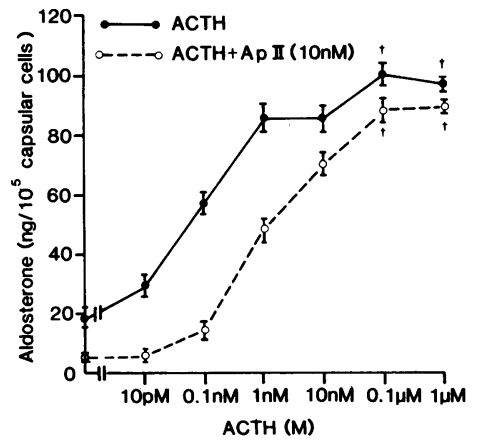

Figure 2. Aldosterone production by ACTH with and without atriopeptin II. Each point represents the mean \pm SE of six experiments done in duplicate, except where indicated by $\dagger$, where $n=3$. In each experiment, ACTH concentrations are expressed as moles per liter of incubation medium. 


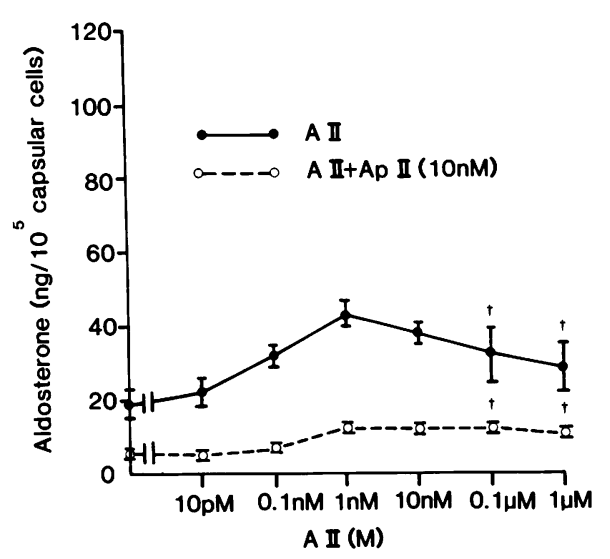

Figure 3. Aldosterone production by angiotensin II with and without atriopeptin II. Each point represents the mean \pm SE of five experiments done in duplicate, except where indicated by $\dagger$, where $n=2$. AII concentrations are expressed as moles per liter of incubation medium.

hibited by atriopeptin II ( $1 \mathrm{nM}$ AII $=23.6 \pm 3.3$ vs. $1 \mathrm{nM} \mathrm{AII} \mathrm{+}$ Ap II $=6.8 \pm 1.4=71 \%$ inhibition, $P<0.01)$. Further increases in the angiotensin II concentrations did not overcome the inhibition by atriopeptin II.

This difference in the inhibitory effect of atriopeptin on the maximal aldosterone response to $\mathrm{ACTH}$, compared with the maximal response to angiotensin II, was also observed when atriopeptin I was used. Aldosterone response to $10 \mathrm{nM} \mathrm{ACTH}$ $=76.6 \pm 5.2$ vs. $10 \mathrm{nM} \mathrm{ACTH}+\mathrm{Ap} \mathrm{I}=74.7 \pm 4.0(n=3)=2 \%$ inhibition. Aldosterone response to $1 \mathrm{nM} \mathrm{AII}=32.6 \pm 3.9$ vs. 1 $\mathrm{nM}$ AII $+\mathrm{Ap} \mathrm{I}=21 \pm 3.5(n=2)=36 \%$ inhibition.

In Fig. 4 the results of the effect of atriopeptin II on the stimulation of corticosterone release by fasciculata cells are shown. Atriopeptin II (10 nM) had no effect on basal or ACTHstimulated corticosterone from $10 \mathrm{pM}$ to $10 \mathrm{nM} \mathrm{ACTH}$.

In vivo experiments. Fig. 5 shows the effect of a simultaneous

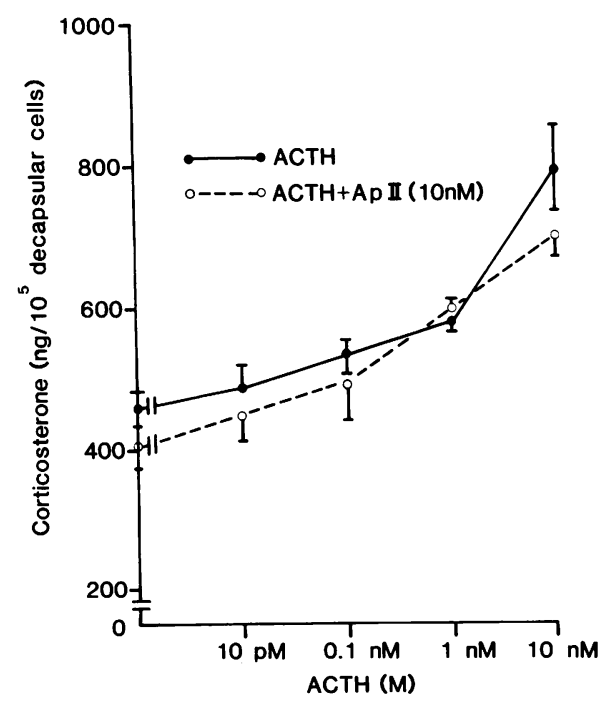

Figure 4. Effect of atriopeptin II on basal and ACTH-stimulated corticosterone production by fasciculata cells. Each point represents the mean $\pm \mathrm{SE}$ of five to six experiments done in duplicate.

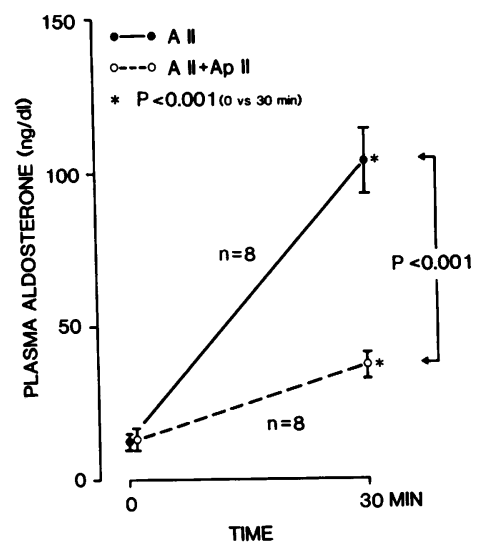

Figure 5. In vivo inhibition by atriopeptin II of plasma aldosterone stimulated by angiotensin II. Angiotensin II was infused either alone or with atriopeptin II. Plasma aldosterone is shown on the ordinate and the time of infusion on the abscissa. $n=8$ means eight rats in each group were studied. ${ }^{*}=P<0.001$.

infusion of atriopeptin II on aldosterone stimulation by angiotensin II. One group of eight rats received only angiotensin II while another group of eight rats received both angiotensin II and atriopeptin II. The angiotensin II infusion alone increased plasma aldosterone from $12.5 \pm 1.2$ to $105 \pm 9.6 \mathrm{ng} / \mathrm{dl}$ (mean $\pm \mathrm{SE}$ ) $(P<0.001)$. When atriopeptin II was infused simultaneously with angiotensin II there was still a significant increase from $14.9 \pm 2.4$ to $37.8 \pm 3.15 \mathrm{ng} / \mathrm{dl}$, but the increase was much less than when angiotensin II was infused alone $(37.8 \pm 3.2$ vs. $105 \pm 9.6 \mathrm{ng} / \mathrm{dl})(P<0.001)$.

In Table I the results from one experiment with four rats in each group in which multiple variables were measured at the end of the infusions are shown. Although atriopeptin II markedly inhibited the aldosterone response to angiotensin II, there was no effect on serum potassium, PRA, and ACTH (as reflected in corticosterone plasma levels). These results suggest a direct inhibition at the adrenal gland. To be more certain of the effect on PRA, a comparison of PRA in seven additional rats in each group was made.

PRA values were not significantly different between the angiotensin II- and the angiotensin II plus atriopeptin II-infused groups ( $5.72 \pm 1.54$ vs. $7.29 \pm 1.74 \mathrm{ng} \mathrm{AI} / \mathrm{ml}$ per h (mean $\pm \mathrm{SE}$ ), $n$ $=11$ in each group).

The hematocrit rose markedly in the atriopeptin-treated rats, possibly as a result of the profound diuresis.

Table I. Effect of Angiotensin II Infusions or Angiotensin II Plus Atriopeptin II on Plasma Levels of Aldosterone, Corticosterone, Potassium, PRA, and Hematocrit

\begin{tabular}{llll}
\hline & AII & AII + AP II & \\
\hline $\begin{array}{l}\text { Aldosterone } \\
(n g / d l)\end{array}$ & $98.50 \pm 19.40$ & $33.80 \pm 5.10$ & $P<0.02$ \\
$\begin{array}{l}\text { Corticosterone } \\
(\mu g / d l)\end{array}$ & $3.98 \pm 1.99$ & $5.67 \pm 1.31$ & NS \\
$\begin{array}{l}\text { Potassium } \\
(m E q / l i t e r)\end{array}$ & $3.75 \pm 0.14$ & $3.83 \pm 0.05$ & NS \\
PRA $(n g A I / m l / h)$ & $9.5 \pm 4.85$ & $12.9 \pm 3.64$ & NS \\
Hematocrit $(\%)$ & $46.60 \pm 0.89$ & $50.90 \pm 0.48$ & $P<0.01$ \\
& & &
\end{tabular}

The results were obtained at the end of the $30-\mathrm{min}$ infusions (mean $\pm \mathrm{SE}$ ) in four rats in each group. 


\section{Discussion}

Although much has been learned regarding the factors that stimulate aldosterone production, such as the renin-angiotensin system, ACTH, and potassium, little is known about factors that might inhibit aldosterone release. Several in vivo studies in animals suggested the presence of an inhibiting system that altered aldosterone secretion. However, identification of the factor(s) responsible for the inhibition of aldosterone secretion has not been accomplished $(14,15)$. Dopamine has been shown to cause a tonic inhibition of aldosterone secretion $(27,28)$, but whether dopamine's effect is exerted at the adrenal level or is centrally mediated is still controversial.

Atrial natriuretic factor has been shown to induce natriuresis and diuresis by a direct effect on the kidney (4). Our previous report was the first publication to show that a factor contained in crude atrial extracts was a potent inhibitor of aldosterone production (16). Subsequently, we showed that atriopeptin I was one of the factors responsible for the inhibition of aldosterone production (23). Since then, other laboratories have confirmed our reports (29-32). In the present communication we demonstrated that the synthetic peptides, atriopeptin I, II, and III, are powerful inhibitors of aldosterone production. Atriopeptin II significantly inhibits aldosterone production by rat glomerulosa cells in vitro at 10-pM concentrations or higher. Atriopeptin II and III appear to be equally potent whereas atriopeptin $I$ is slightly less potent. Moreover, atriopeptin II decreased the sensitivity of the glomerulosa cells to ACTH and angiotensin II. However, concentrations of $10 \mathrm{nM} \mathrm{ACTH}$ or greater appeared to overcome the inhibitory effects of atriopeptin II, suggesting a possible competitive interaction. In contrast, high concentrations of angiotensin II did not overcome the inhibitory effect of atriopeptin II. This difference in aldosterone dose-response curve to ACTH or angiotensin II was also observed when either atriopeptin I or crude atrial extracts were used as the inhibitor $(16,23)$.

It appears, therefore, that the atrial peptides have different mechanisms of inhibition of the adrenal response to ACTH and angiotensin II.

Atriopeptin II infusions caused a marked inhibition of the aldosterone response to angiotensin II in vivo without a significant change in plasma renin activity or serum potassium levels and in spite of significant contraction of the intravascular volume as indicated by the increased hematocrit. These data suggest that atriopeptins are the aldosterone-inhibiting factors present in crude atrial extracts. In addition to the direct natriuretic effect on the kidney, probably due to an increase in glomerular filtration rate, atriopeptins may affect sodium balance by inhibiting aldosterone production. The mechanism by which atriopeptins inhibit aldosterone production is not known.

In conclusion, the atriopeptins have powerful inhibitory actions on aldosterone production in vitro and in vivo. Whether these peptides are physiological inhibitors of aldosterone secretion remains to be determined.

\section{References}

1. deBold, A. J., H. B. Borenstein, A. T. Veress, and H. Sonnenberg. 1981. A rapid and potent natriuretic response to intravenous injection of atrial myocardial extract in rats. Life Sci. 28:89-94.

2. Sonnenberg, H., W. A. Cupples, A. J. deBold, and A. T. Veress.
1981. Intrarenal localization of the natriuretic effect of cardiac atrial extract. Can. J. Physiol. Pharmacol. 60:1149-1152.

3. Trippodo, N. C., A. A. MacPhee, F. E. Cole, and H. L. Blakesley. 1982. Partial chemical characterization of a natriuretic substance in rat atrial heart tissue. Proc. Soc. Exp. Biol. Med. 170:502-508.

4. Keeler, R. 1982. Atrial natriuretic factor has a direct, prostaglandinindependent action on kidneys. Can. J. Physiol. Pharmacol. 60:10781082.

5. deBold, A. J. 1982. Atrial natriuretic factor of the rat heart. Studies on isolation and properties. Proc. Soc. Exp. Biol. Med. 170:133-138.

6. Trippodo, N. C., A. A. MacPhee, and F. E. Cole. 1983. Partially purified human and rat atrial natriuretic factor. Hypertension. 5(Suppl. I):I-81-I-88.

7. Flynn, T. G., M. deBold, and A. J. deBold. 1983. The amino acid sequence of an atrial peptide with potent diuretic and natriuretic properties. Biochem. Biophys. Res. Commun. 117:859-865.

8. Currie, M. G., D. M. Geller, B. R. Cole, J. G. Boylan, W. YuSheng, S. W. Holmberg, and P. Needleman. 1983. Bioactive cardiac substances: potent vasorelaxant activity in mammalian atria. Science (Wash. DC). 221:71-73.

9. Currie, M. G., D. M. Geller, B. R. Cole, W. R. Siegel, K. F. Fok, S. B. Adams, S. R. Eubanks, G. R. Galluppi, and P. Needleman. 1984. Purification and sequence analysis of bioactive atrial peptides (atriopeptins). Science (Wash. DC). 223:67-69.

10. Geller, D. M., M. G. Currie, K. Wakitani, B. R. Cole, S. P. Adams, K. F. Fok, N. R. Siegel, S. R. Eubanks, S. E. Galluppi, and P. Needleman. 1984. Atriopeptins: a family of potent biologically active peptides derived from mammalian atria. Biochem. Biophys. Res. Commun. 120:333-338.

11. Jamieson, J. D., and G. E. Palade. 1964. Specific granules in atrial muscle cells. J. Cell. Biol. 23:151-172.

12. deBold, A. J. 1982. Tissue fractionation studies on the relationship between an atrial natriuretic factor and specific atrial granules. Can. J. Physiol. Pharmacol. 60:324-330.

13. Garcia, R., M. Cantin, G. Thibault, H. Ong, and J. Genest. 1982. Relationship of specific granules to the natriuretic and diuretic activity of rat atria. Experientia (Basel). 38:1071-1073.

14. Anderson, C. H., M. McCally, and G. L. Farrell. 1959. The effects of atrial stretch on aldosterone secretion. Endocrinology. 64:202-207.

15. Gann, D. S., and R. H. Travis. 1964. Mechanisms of hemodynamic control of secretion of aldosterone in the dog. Am. J. Physiol. 207:1095-1101.

16. Atarashi, K., P. J. Mulrow, R. Franco-Saenz, R. Snajdar, and J. P. Rapp. 1984. Inhibition of aldosterone production by an atrial extract. Science (Wash. DC). 224:992-993.

17. Kangawa, K., and H. Matsuo. 1984. Purification and complete amino acid sequence of $\alpha$-human atrial natriuretic polypeptide ( $\alpha$-hANP). Biochem. Biophys. Res. Commun. 118(1):131-139.

18. Atlas, S. A., H. D. Kleinert, M. J. Camargo, A. Januszewicz, J. E. Sealy, J. H. Laragh, J. W. Schilling, J. A. Lewicki, L. K. Johnson, and T. Maack. 1984. Purification sequencing and synthesis of natriuretic and vasoactive rat atrial peptide. Nature (Lond.). 309:717-719.

19. Yamanaka, M., B. Greenberg, L. Johnson, J. Seilhamer, M. Brewer, T. Friedemann, J. Miller, S. Atlas, J. Laragh, J. Lewicki, and J. Fiddes. 1984. Cloning and sequence analysis of the cDNA for the rat atrial natriuretic factor precursor. Nature (Lond.). 309:719-722.

20. Maki, M., R. Takayanagi, K. S. Misono, K. N. Pandey, C. Tibbetts, and T. Inagami. 1984. Structure of rat atrial natriuretic factor precursor deduced from cDNA sequence. Nature (Lond.). 309:722-724.

21. Oikawa, S., M. Imai, A. Veno, S. Tanaka, T. Noguchi, H. Nakazato, K. Kangawa, A. Fukuda, and H. Matsuo. 1984. Cloning and sequence analysis of cDNA encoding a precursor for human atrial natriuretic polypeptide. Nature (Lond.). 309:724-726.

22. Nakayama, K., H. Ohkubo, T. Hirose, S. Inayama, and S. Nakanishi. 1984. mRNA sequence for human cardiodilatin-atrial natriuretic factor precursor and regulation of precursor in mRNA in rat atria. Nature (Lond.). 310:699-701. 
23. Atarashi, K., R. Franco-Saenz, P. J. Mulrow, R. Snajdar, and J. P. Rapp. 1984. Inhibition of aldosterone production by atrial natriuretic factor. J. Hypertension. 2(Suppl. 3):293-295.

24. Matsuoka, H., S. Y. Tan, and P. J. Mulrow. 1980. Effects of prostaglandins on adrenal steroidogenesis in the rats. Prostaglandins. 19: 91-298.

25. Tan, S. Y., R. Noth, and P. J. Mulrow. 1978. Direct non-chromatographic radioimmunoassay of aldosterone: validation and a commercially available kit and observations on age-related change in concentrations in plasma. Clin. Chem. 24:1531-1533.

26. Mayes, D. M. 1981. Plasma Corticosterone Radioimmunoassay Procedure Manual: antiserum B-3-163. Endocrine Science Laboratory, Tarzana, CA. 1-15.

27. Noth, R. H., R. W. McCallum, G. Contine, and J. Havelick. 1980. Tonic dopaminergic suppression of plasma aldosterone. J. Clin. Endocrinol. Metab. 51:64-69.

28. Carey, R. M., M. O. Thorner, and E. M. Ortt. 1979. Effects of metoclopramide and bromocriptine on the renin-angiotensin-aldosterone system in man. Dopaminergic control of aldosterone. J. Clin. Invest. 63: 727-735.

29. De Lean, A., K. Racz, J. Gutkowska, T-T Nguyen, M. Cantin, and G. Genest. 1984. Specific receptor mediated inhibition by synthetic atrial natriuretic factor of hormone stimulated steroidogenesis in cultured bovine adrenal cells. Endocrinology. 115:1636-1638.

30. Goodfriend, T. L., M. E. Elliot, and S. A. Atlas. 1984. Actions of synthetic atrial natriuretic factor on bovine adrenal glomerulosa. Life Sci. 35:1675-1682.

31. Kudo, T., and A. Baird. 1984. Inhibition of aldosterone production in the adrenal glomerulosa by atrial natriuretic factor. Nature (Lond.). 312:756-757.

32. Chartier, L., E. L. Schiffrin, G. Thibault, and R. Garcia. 1984. Atrial natriuretic factor inhibits the effect of angiotensin II, acth and potassium on aldosterone secretion in vitro and angiotensin II induced steroidogenesis in vivo. Endocrinology. 115:2026-2028. 